\title{
A morphological and genetic description of pentastomid infective nymphs belonging to the family Sebekidae Sambon, 1922 in fish in Australian waters
}

\author{
Diane P. Barton ${ }^{1,2,3}$ and Jess A.T. Morgan $^{4,5}$ \\ ${ }^{1}$ Fisheries Research, Department of Primary Industries \& Fisheries, Berrimah Farm, Darwin, Northern Territory, Australia; \\ ${ }^{2}$ Research Institute for the Environment and Livelihoods, Charles Darwin University, Darwin, Northern Territory, Australia; \\ ${ }^{3}$ Museum and Art Gallery of the Northern Territory, Conacher Street, Fannie Bay, Darwin, Northern Territory, Australia; \\ ${ }^{4}$ Queensland Alliance for Agriculture and Food Innovation, Centre for Animal Science, The University of Queensland, St. Lucia, \\ Queensland, Australia; \\ ${ }^{5}$ Animal Science, Queensland Department of Agriculture and Fisheries, EcoSciences Precinct, Dutton Park, Queensland, Australia
}

\begin{abstract}
Infective nymphal stages of the family Sebekidae Sambon, 1922 are reported from four species of fish in Australian waters for the first time. Infected fish were collected from locations in Western Australia, the Northern Territory and north Queensland. The infective nymphs of Alofia merki Giglioli in Sambon, 1922 and Sebekia purdieae Riley, Spratt et Winch, 1990 are reported and described for the first time. The remaining specimens were identified as belonging to the genus Sebekia Sambon, 1922 based on the combination of buccal cadre shape, shape and size of hooks, and overall body size, but could not be attributed to any of the other species of Sebekia already reported due to missing required morphological features. DNA sequences of members of the family Sebekidae are presented for the first time. The lack of knowledge on the pentastome fauna of wild crocodiles, and any potential intermediate hosts, in northern Australia, is also outlined.
\end{abstract}

Keywords: Protonibea, Lutjanus, Lates, Ambassis, intermediate host, DNA

This article contains supporting information (Tables S1-S6) online at http://folia.paru.cas.cz/supp1/2016-63-026.pdf

During a survey of the parasite fauna of various fish species in northern Australian waters, pentastomid infective nymphs, identified as belonging to the family Sebekidae Sambon, 1922, were collected. Although commonly reported within fish hosts elsewhere (Junker et al. 1998, Guidelli et al. 2003, Almeida et al. 2010, Giesen et al. 2013), no larval pentastomids have previously been reported from fish in Australian waters.

Descriptions of infective nymphal stages of many of the sebekid species are not available, making identification of infections from intermediate hosts difficult. However, Winch and Riley (1986) suggested that the infective larvae of Sebekia oxycephala (Diesing, 1836) (collected from fish) possessed the final number of annuli as for the adult stage. Infective nymphs were identified as those in possession of 'double hooks' (i.e. hooks with the dorsal accessory piece) and well defined annuli fringed by a single row of spines (Winch and Riley 1986). If this is true for all sebekids, the nymphal stages collected in this study were infective and could potentially be identified to species by annulus count.
Most larval sebekid pentastomes reported from fish mature in crocodiles (Junker et al. 1998, Guidelli et al. 2003, Almeida et al. 2010, Giesen et al. 2013), with a few species maturing in freshwater turtles (Curran et al. 2014). Crocodiles in the Northern Territory, Australia, have been reported with at least five species belonging to three genera, all Sebekidae, from both wild and farmed populations (Riley et al. 1985, 1990, Riley 1994, Riley and Hurchzermeyer 1996). At present, however, nymphs (also collected from crocodiles) have only been described for two of those species (Riley et al. 1990).

Although the distribution of crocodiles ranges across the whole of northern Australia (Webb and Manolis 1989), including areas of Western Australia and Queensland, no pentastomes have been reported from crocodiles outside of the Northern Territory. Little is known about the ecology of infection of pentastomids in wild crocodiles in northern Australia or of their distribution in potential intermediate hosts.

This paper presents the first record of nymphal pentastomes from fish in Australian waters and also provides the 
Table 1. Locations of fish collected from along the coastlines of Western Australia (WA), the Northern Territory (NT) and Queensland (QLD) examined in the present study. Locations are listed in order travelling from west to east. Number of fish examined from each location is presented, with the range in $\mathrm{mm}$, mean of total length (TL) in parentheses.

\begin{tabular}{|c|c|c|c|c|c|c|c|}
\hline \multirow[b]{2}{*}{ State } & \multirow[b]{2}{*}{ Location } & \multicolumn{2}{|c|}{ Protonibea diacanthus (Lacepède) } & \multicolumn{2}{|c|}{ Lutjanus johnii (Bloch) } & \multicolumn{2}{|c|}{ Lethrinus laticaudis Alleyne et Macleay } \\
\hline & & No. & Mean TL & No. & Mean TL & No. & Mean TL \\
\hline \multirow{4}{*}{ WA } & Pilbara & - & - & - & - & 69 & $259-492(363)$ \\
\hline & Broome & 36 & $720-1199(1019)$ & - & - & - & - \\
\hline & Kimberleys & 20 & $520-920(647)$ & 61 & $240-689(379)$ & 101 & $220-477(333)$ \\
\hline & Wyndham & $34 *$ & $804-1220(1067)$ & - & - & - & - \\
\hline \multirow{13}{*}{ NT } & Bonaparte Gulf & - & - & 23 & $447-569(517)$ & - & - \\
\hline & Wadeye & 25 & $540-1160(789)$ & 27 & $415-560(463)$ & 30 & $290-440(396)$ \\
\hline & Bynoe Harbour & 25 & N/A & 26 & $250-545(352)$ & 11 & $220-480(341)$ \\
\hline & Darwin Harbour & 26 & $395-1150(654)$ & 75 & $150-710(344)$ & 56 & $175-395(257)$ \\
\hline & Cape Hotham & $10 *$ & $430-1230$ (990) & 9 & $345-425(383)$ & - & - \\
\hline & Bathurst Island & $28 *$ & $387-1235(969)^{\dagger}$ & 36 & $247-540(379)$ & - & - \\
\hline & Melville Island & 30 & $405-1170(646)$ & 31 & $240-595(339)$ & - & - \\
\hline & Coburg Peninsula & - & - & 35 & $322-631(461)$ & 33 & $230-370(309)$ \\
\hline & Maningrida & $29^{*}$ & $420-1210(731)$ & 16 & $270-510(368)$ & - & - \\
\hline & Arnhem Land & 19 & N/A & 66 & $200-625(411)$ & - & - \\
\hline & Gove & 1 & 360 & - & - & - & - \\
\hline & Groote Eylandt/Blue Mud Bay & 3 & $580-850(760)$ & 58 & $370-770(523)$ & 29 & $260-380(307)$ \\
\hline & Borroloola & 29 & $440-740(588)$ & 25 & $310-645(407)$ & 30 & $245-433(308)$ \\
\hline \multirow{4}{*}{ QLD } & Gulf of Carpentaria & - & - & 21 & $355-710(537)$ & 3 & $323-343$ (333) \\
\hline & Halifax Bay & - & - & $51^{*}$ & $364-822(596)$ & 14 & $239-405(354)$ \\
\hline & South East Qld & - & - & - & - & 37 & $268-547(383)$ \\
\hline & Total & 315 & & 560 & & 413 & \\
\hline
\end{tabular}

* infected fish - data regarding these locations are presented in the text; N/A - fish where TL data was not obtained; † fish collected from Aspley Strait not included in TL data presented.

first DNA sequences of members of the Sebekidae which will aid in future diagnostics of the group.

\section{MATERIALS AND METHODS}

Fish from the following species were examined for parasites as elements of a larger project: the black jewfish, Protonibea diacanthus (Lacepède) (Sciaenidae), the golden snapper, Lutjanus johnii (Bloch) (Lutjanidae) and the grass emperor, Lethrinus laticaudis Alleyne et Macleay (Lethrinidae). Of these species, fish belonging to $P$. diacanthus and L. johnii were found to be infected with pentastomid nymphs (Table 1).

Infected $P$. diacanthus were collected from four separate locations: Wyndham (Western Australia), Cape Hotham, Bathurst Island and Maningrida (the Northern Territory). A total of 34 $P$. diacanthus were collected from Cambridge Gulf, near Wyndham (14'49'22"S; $\left.128^{\circ} 17^{\prime} 15^{\prime \prime} \mathrm{E}\right)$ in May and June 2015. A total of 10 P. diacanthus were collected from Cape Hotham in August 2013 and April and May 2014. Two sites were sampled at Cape Hotham: Ruby Island off the eastern tip and the mouth of the Adelaide River at the western base. Four $P$. diacanthus were collected from Ruby Island (1206'28"S; $\left.131^{\circ} 20^{\prime} 59^{\prime \prime} \mathrm{E}\right)$ on 30 August 2013. Six $P$. diacanthus were collected from the mouth of the Adelaide River (12 $\left.13^{\prime} 12^{\prime \prime} \mathrm{S} ; 131^{\circ} 14^{\prime} 1.5^{\prime \prime} \mathrm{E}\right)$ between 25 April and 11 May 2014. Four sites were sampled around Bathurst Island: Port Hurd (western side), Caution Point (western side), St Asaph Bay (northern side), and Aspley Straits (running between Bathurst and Melville Islands). Three $P$. diacanthus were collected from Port

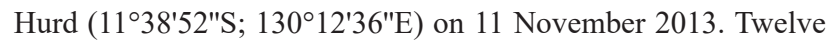
P. diacanthus were collected from Caution Point $\left(11^{\circ} 23^{\prime} 13.5^{\prime \prime S}\right.$; $\left.130^{\circ} 08^{\prime} 56^{\prime \prime E}\right)$ on 18 November 2014. Four P. diacanthus were

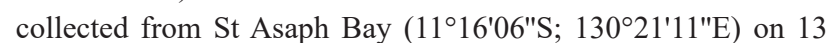

August 2015. Nine $P$. diacanthus were collected from the Aspley Strait (11 $\left.{ }^{\circ} 29^{\prime} 57 \mathrm{~S}^{\prime \prime} ; 130^{\circ} 24^{\prime} 32^{\prime \prime} \mathrm{E}\right)$ on 10 September 2015. A total of 29 P. diacanthus were collected from Maningrida in August 2014 and July 2015. Two sites were sampled near Maningrida: Liverpool River and Blythe River. Twenty-four P. diacanthus were collected from the Liverpool River $\left(12^{\circ} 04^{\prime} 16^{\prime \prime S}\right.$; $\left.134^{\circ} 11^{\prime} 21^{\prime \prime} \mathrm{E}\right)$ on 25-27 August 2014. Five $P$. diacanthus were collected from the Blythe River (12 $05^{\prime} 38^{\prime \prime}$ S; 134³6'09") on 28 July 2015.

Infected L. johnii were collected from Halifax Bay, north of Townsville, northern Queensland (18²'14"S; 146 21'11"E). A total of 51 L. johnii were collected from May to December 2014.

All fish were euthanased (Charles Darwin University Animal Ethics Approval A13014), placed on ice and transported to the laboratory for processing; some fish were frozen whole prior to processing. All internal organs were removed for examination for parasites. The intestinal tract, and associated mesenteries, were separated, placed in saline and examined under a dissector microscope for the presence of parasites. Pentastome nymphs were found encysted in the mesenteries along the intestinal system. The nymphs were removed from their cysts and preserved in $70 \%$ ethanol.

Nymphs were cleared using lactophenol solution and observed intact or partially intact using light microscopy. Hooks and the oral cadre were dissected from some specimens. Hook dimensions measured were blade length (AC), hook length (AD), base length $(\mathrm{BC})$, plateau length $(\mathrm{CD})$, and hook gape (AB) (Fig. 1). Buccal cadre measurements were of buccal cadre length and maximum width of buccal cadre.

Drawings were made with the use of a drawing tube. Photos were taken using a 9MP Microscope Digital Camera (AmScope 


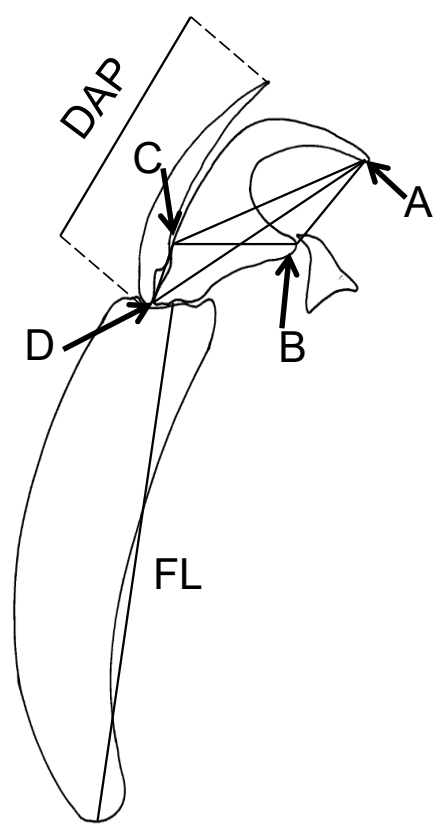

Fig. 1. Template for measurement conventions of nymphal hook, fulcrum and dorsal accessory piece. $\mathrm{AB}$ - hook gape; $\mathrm{AC}$ - blade length; $\mathrm{AD}$ - hook length; $\mathrm{BC}$ - base length; $\mathrm{CD}$ - plateau length; DAP - length of dorsal accessory piece; FL - fulcrum length.

Model MU900). Measurements of specimens were made using a calibrated eyepiece; measurements are presented in micrometers, unless otherwise stated; the range is followed by the mean in parentheses. Width measurements represent maximum width.

DNA was extracted from a $5 \mathrm{~mm}$ section from a total of 22 nymphs using a QIAamp DNA Mini Kit (Qiagen, Doncaster, Victoria, Australia) following the manufacturer's instructions. Mitochondrial DNA was amplified from a partial region of the cytochrome oxidase 1 ( coxl) gene between primers jgHCO2198 (5'TITCIACIAAYCAYAARGAYATTGG) and jgLCO1490 (5'TAIACYTCIGGRTGICCRAARAAYCA) (Geller et al. 2013). The nuclear ribosomal DNA small subunit, 18S, was amplified and sequenced using primers 18S_1F (5'TACCTGGTTGATCCTGCCAGT) modified from Raupach et al. (2009), 18S_1000F (5'CGATCAGATACCGCCCTAGTTC) (Dreyer and Wagele 2001) and 18S_1800R (GATCCTTCCGCAGGTTCACCTACG) (Raupach et al. 2009). The nuclear ribosomal large subunit, 28S, was amplified and sequenced using primers 28S_22F (5'GWRRYWACCCGCTGAAYTWAAGC) (designed by authors) and 28S_1300R (5'CTGGCGATCGATTTGCACGTCAG) (modified from Sonnenberg et al. 2007). DNA could not be extracted from two nymphs, most likely due to storage in lactophenol for a significant period of time; it was noted that DNA could still successfully be extracted from specimens briefly stored in lactophenol (to allow for counting of annuli).

Amplification reactions were carried out in $10 \mu \mathrm{l}$ volumes containing $1 \mu \mathrm{M}$ of each primer pair, combined with $10-100 \mathrm{ng}$ of extracted DNA, $10 \times$ HotMaster Taq buffer ( 5 Prime, distributed by VWR International, Tingalpa, Queensland, Australia, containing $25 \mathrm{mM}$ magnesium), $1 \mathrm{mM}$ dNTP, and 1 unit of HotMaster Taq DNA polymerase (5 Prime). Thermal cycling conditions consisted of an initial denaturation $\left(94^{\circ} \mathrm{C}\right.$ for 3 minutes) followed by 35 cycles of $94^{\circ} \mathrm{C}$ for $30 \mathrm{~s}$, annealing at $50^{\circ} \mathrm{C}$ for $30 \mathrm{~s}$ and extension at $72^{\circ} \mathrm{C}$ for $1 \mathrm{~min} 30 \mathrm{~s}$, with a final extension step of $72^{\circ} \mathrm{C}$ for
7 min. Cycling was performed in a Biorad thermal cycler (DNA Engine Peltier, Biorad, Gladesville, NSW, Australia). PCR products were viewed on a $1 \%$ agarose TBE gel stained with GelRed (Biotium, USA distributed by Gene Target Solutions, Dural, New South Wales, Australia). Prior to sequencing PCR products were desalted using Exosap-it ${ }^{\circledR}$ (USB Corporation distributed by GE Healthcare Bio-Sciences, Rydalmere, NSW, Australia). Approximately $20 \mathrm{ng}$ of PCR product was used in standard ABI Dye Terminator sequencing reactions using Big Dye Vers 3.1 technology (Applied Biosystems, Thermo-Fisher Scientific, Scoresby, Victroia, Australia) and were run on an 3130xl Genetic Analyser (Applied Biosystems). Forward and reverse sequences were edited and aligned using Sequencher (Vers 4.10.1 Gene Codes Corporation, Ann Arbor, MI, USA). Sequences were deposited in Genbank (Alofia merki Giglioli in Sambon, 1922 KU975378, KU975382-KU975385; Sebekia purdieae Riley, Spratt et Winch, 1990 KU975377, 975381, 975386; Sebekia sp. 2 KU975375, 975379, 975387; Sebekia sp. 3 KU975376, 955380).

Publically available sequences from related families in the order Porocephalida (Linguatuloidea: Porocephalidae) were downloaded from NCBI (http://www.ncbi.nlm.nih.gov) and included for phylogenetic comparison. The genus Raillietiella Sambon, 1922, a representative of the sister order Raillietiellida, was used as outgroup to root all phylogenetic trees. Sequences were aligned in Geneious R8 (Kearse et al. 2012) using the Muscle algorithm using the default settings. Sequence alignments were truncated to the shortest sequence prior to phylogenetic tree construction. Neighbour joining trees were constructed in Geneious R8 (Kearse et al. 2012) using a Tamura-Nei distance model. Branch support was determined in Geneious R8 (Kearse et al. 2012) using bootstrap resampling with 1000 replicates.

Specimens of Alofia merki (SAM C5666-5670), A. ginae Giglioli in Sambon, 1922 (SAM C5671), Sebekia johnstoni Riley, Spratt et Winch, 1990 (SAM C5700, C5740), S. multiannulata Riley, Spratt et Winch, 1990 (SAM C5739, C5677, C5679, C5739), S. purdieae (SAM C5731, C5732, C5680, C5733) and unidentified pentastomid nymphs collected from a Lates calcarifer (Bloch) (Latidae; collected by Kate Hutson 21 March 2011 from Cleveland Bay, Townsville, north Queensland; SAM C7879) were borrowed from the South Australian Museum, and a collection of nymphs of Sebekia sp. collected from Ambassis macleayi (Castelnau) (Ambassidae; collected by John Purdie on 23 August 1985 from the Noonamah Crocodile Farm, Noonamah, Northern Territory; AWC P31) was borrowed from the Australian Wildlife Collection, CSIRO, Crace, ACT, for comparison with the collected specimens. Voucher specimens were deposited in the collections of the Museum and Art Gallery of the Northern Territory (NTM) and the South Australian Museum (SAM) as indicated in Tables S1-S6.

\section{RESULTS}

In total, 12 Protonibea diacanthus $(3.8 \%$ of all $P$. diacanthus examined) were infected with pentastome nymphs, with a mean intensity of 3.1 (1-14) and 2 Lutjanus johnii ( $0.4 \%$ of all $L$. johnii examined) were infected with a single pentastome nymph each. A total of 39 nymphs were collected from $P$. diacanthus and L. johnii in the present study; combined with the 3 nymphs collected from the Lates calcarifer (SAM C7879) and the 12 nymphs collected from 

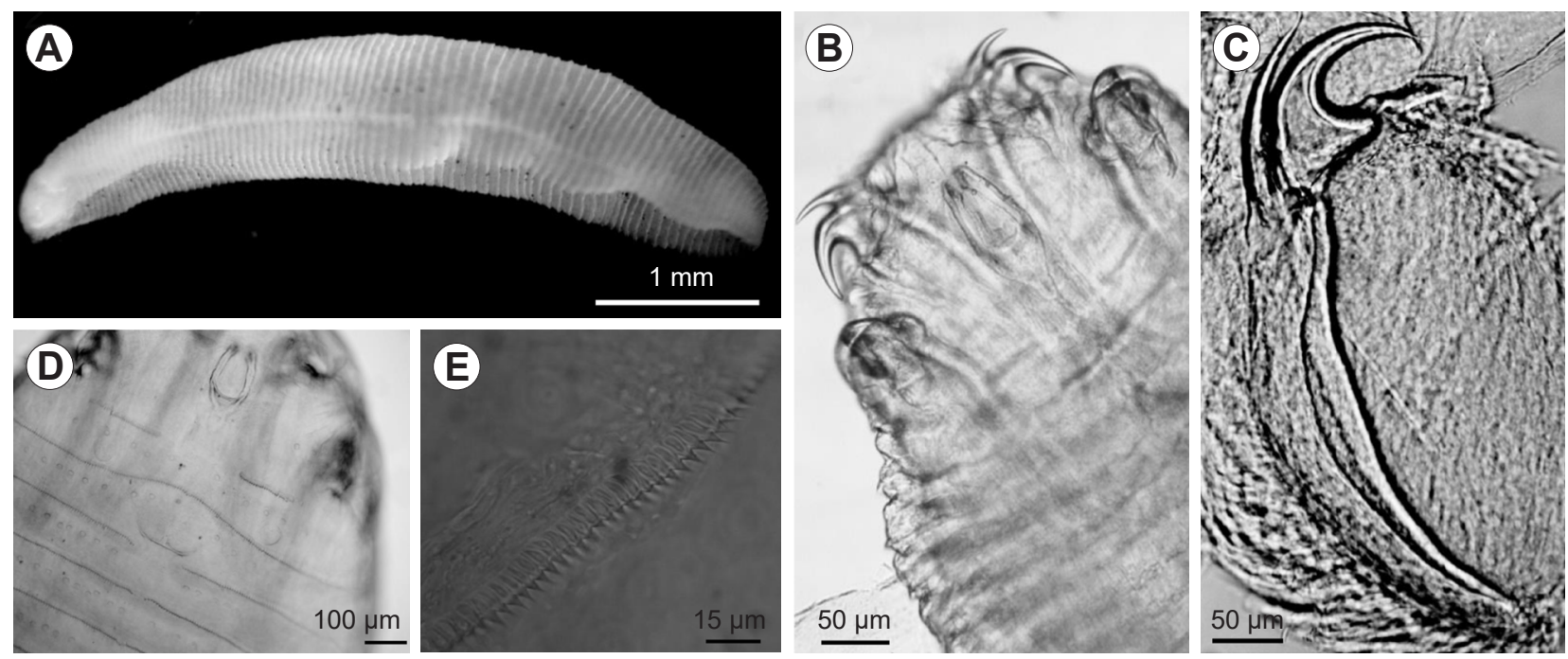

Fig. 2. Nymph of Alofia merki Giglioli in Sambon, 1922 from Lates calcarifer (Bloch) (A) and from Protonibea diacanthus (Lacepède) (B-E). A - whole specimen showing conspicuous abdominal annuli (SAM C7879-1), anterior end of specimen oriented to the left; B - anterior end showing position of buccal cadre relative to hooks and fulcra (NTM D1536); C - anterior hook and fulcrum (SAM C9428); D - position of male genital pore relative to position of buccal cadre (NTM D1547), chloride cells also apparent on each annulus; $\mathbf{E}$ - spines of annulus (NTM D1537) showing basal swelling embedded in cuticle.

A. macleayi (AWC P31), gave a total of 54 nymphs. All nymphs were identified as members of the Sebekidae based on overall morphology, buccal cadre morphology and being located within a fish host. All nymphs examined, with the exception of one collected from L. johnii, were infective, based on the description of nymphal development, including the infective stage, of $S$. oxycephala by Winch and Riley (1986); measurements presented do not include the non-infective nymph.

\section{Alofia merki Giglioli in Sambon, 1922}

Fig. 2

Description. Infective nymphs (based on 34 specimens). Fresh specimens off-white in colour. Body 3.9-9.8 mm (7.1 mm) long by 700-1300 (952) wide. Annuli margins easily discernible in whole mounts (Fig. 2A), total count, including annuli with interrupted rows of spines, 72-83 (78). Annuli 57-65 wide (near anterior end) to 32-41 wide (at posterior end).

Hooks arranged in trapezoid pattern around mouth opening (Fig. 2B). Anterior and posterior hooks sharptipped, all with dorsal accessory piece (Fig. 2C). Hooks and dorsal accessory pieces visible under dissector microscope. Fulcra long, stout, slightly curved. Anterior hooks: dorsal accessory piece $90-179(135, \mathrm{n}=31)$, AC 99-145 $(118, \mathrm{n}=29)$, AD 112-163 (137, $\mathrm{n}=26), \mathrm{BC} 64-90$ (75, $\mathrm{n}=29)$, CD $24-64(40, \mathrm{n}=24), \mathrm{AB} 38-80(59, \mathrm{n}=29)$, fulcrum length 236-424 $(350, n=32)$; posterior hooks: dorsal accessory piece 115-196 (138, $\mathrm{n}=26), \mathrm{AC} 99-141(120$, $\mathrm{n}=25)$, AD 122-163 (142, $\mathrm{n}=24), \mathrm{BC} 63-90(79, \mathrm{n}=25)$, CD 25-64 (42, n = 24), AB 42-90 (58, $\mathrm{n}=25)$, fulcrum length $212-416(335, n=31)$. Measurements for individual nymphs are presented in Tables S1-S4.

Buccal cadre U-shaped (Fig. 2B), open anteriorly; internal edge of opening 'serrated'. Parallel sides of cadre thick, crenulated along length. Posterior edge of oral cadre rounded, thick, tapering into peg-like extension into oe- sophagous. Oral cadre situated between fulcra of anterior hook pair; anterior edge of oral cadre at approximate level of posterior edge of anterior hooks. Buccal cadre, including peg-like extension, 139-253 (195) long by 32-118 (87) wide.

Body carries conspicuous rows of sharply pointed projecting spines along posterior edge of each annulus (Fig. 2D,E). First row interrupted (Fig. 2D). Spines obvious, present on each annulus. Total length of spines 16 (in anterior part of body), of which 10 embedded in cuticle in basal swelling (Fig. 2E). Chloride cells disposed in single row along anterior edge of annuli (Fig. 2D). Chloride cells measure $10-13$ in diameter.

Anus terminal; rectum lined with thin cuticle. In female nymphs, where visible, vulva located 2 annuli from anus, vertical slit 64 long, covering two annuli. In male nymphs genital pore located on posterior edge of second annulus (Fig. 2D).

Hosts: Protonibea diacanthus (Lacepède) (Sciaenidae), Lutjanus johnii (Bloch) (Lutjanidae), Lates calcarifer (Bloch) (Latidae).

Site of infection: Encysted within capsule within host mesentery tissues.

L o c a lities: Wyndham, Port Hurd, Adelaide River, Halifax Bay, Townsville (see Materials and Methods for details).

Prevalence and intensity: Protonibea diacanthus: overall 14 of 315 (3.5\%), 2.6 (1-11); Wyndham 8 of 34 (24\%), 2.75 (1-8), Port Hurd 1 of 3 (33\%), 3; Adelaide River 2 of 6 (33\%), 2. Lutjanus johnii: overall 2 of $560(0.4 \%), 1$; Halifax Bay 2 of 51 (4\%), 1. Lates calcarifer: unknown.

Remarks. Alofia was erected by Giglioli (1922) based on the examination of material within the collection of the Museum of Natural History, Innsbruck, Austria. For most of the material, including the type species, the hosts were unknown and the location of collection considered dubi- 

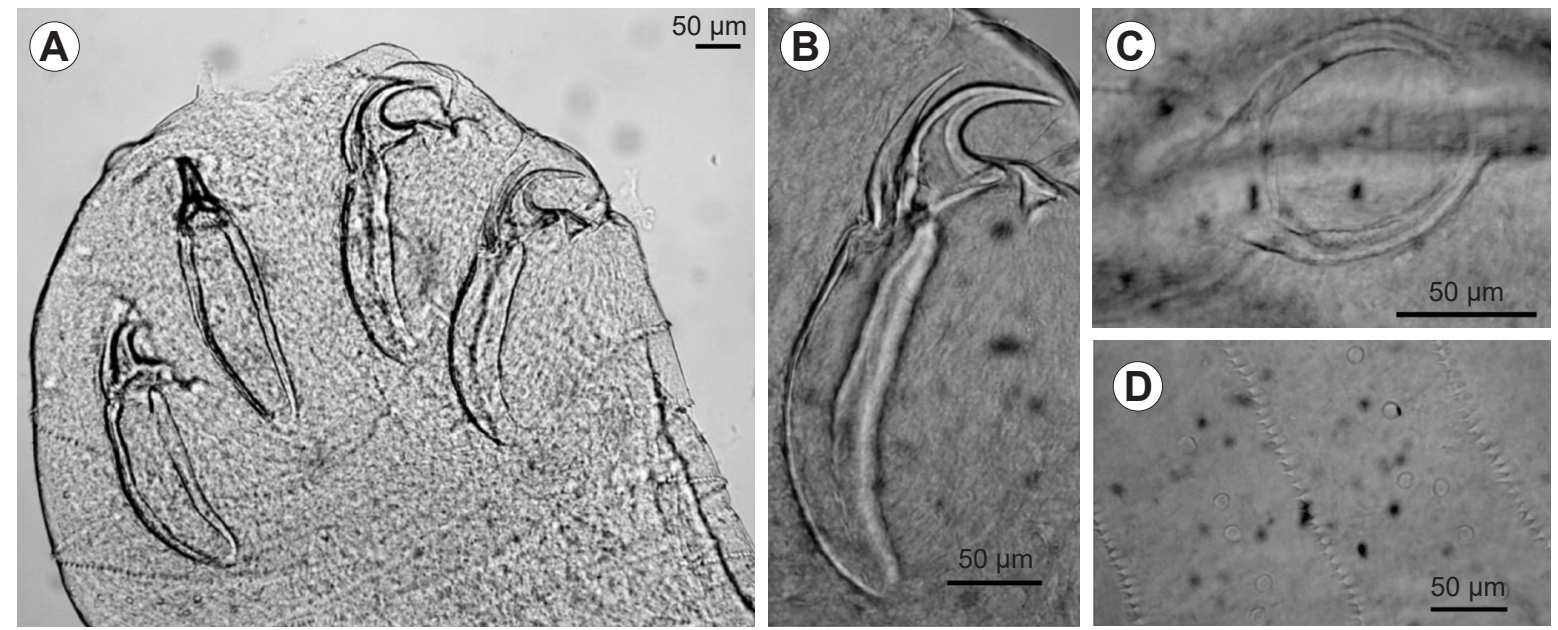

Fig. 3. Nymph of Sebekia purdieae (NTM D1563) from Protonibea diacanthus (Lacepède). A - anterior end showing hooks and fulcra, buccal cadre is apparent as faint outline overlying right anterior fulcrum; B - posterior hook and fulcrum; C - buccal cadre; D - detail of cuticle showing annular spines and chloride cells.

ous (see Riley 1994, for a review). Self and Rego (1985) postulated that all the material studied by Giglioli (1922) in fact may have come from South America, not Samoa, as stated. This was mainly due to the thought that crocodiles did not occur in Samoa and thus a crocodile parasite could not be obtained from there. This was later refuted by Riley (1994) in his review where he validated the genus and its species through the collection of more specimens from known hosts and locations.

Only one species, A. merki, has been reported from an Australian host, Crocodylus porosus (Schneider), from both wild and farmed populations throughout the Northern Territory (Riley 1994). Alofia ginae has also been reported from C. porosus, but only from the Philippines (confirmed host) and possibly also Samoa (presumed host) (Riley 1994). Annulus count of the nymphs collected in this study ranged from 72 to 83 , which covers the reported range for both A. merki (75-77) and A. ginae (75). No description of nymphal A. merki or A. ginae exists for comparison with the specimens collected here. The substantial variation in measurements of various morphological features, including hook dimensions (see Tables S1-S4) across the nymphs may be a reflection of a difference in level of sexual developmental or could be a true reflection of the amount of variability present within a single species. It does show, undoubtedly, the need for a number of specimens to be examined and for genetic analysis to confirm species identifications.

A total of 35 nymphs were identified as members of the genus Alofia based on the shape of the buccal cadre, which is open anteriorly, with nearly parallel sides, a thick chitinous rim, and a peg-like extension into the oesophagous (the 'tuning fork' morphology as described by Riley 1994). DNA analysis confirmed that a single species of Alofia was present (identical sequences obtained for both ribosomal DNA $18 \mathrm{~S}$ and $28 \mathrm{~S}$ ), although three slightly different (one base mutation) mtDNA coxl variants were found among the nymphs. Of the 14 specimens that returned a $100 \%$ match (Alofia 1 in Tables S1-S3), 13 were collected from $P$. diacanthus from Wyndham and the Adelaide River and the remaining specimen was collected from $L$. johnii. Two specimens, collected from $P$. diacanthus at each of Wyndham and Port Hurd, differed by one nucleotide (Alofia 2); one specimen collected from L. calcarifer in Townsville differed by a different nucleotide (Alofia 3 ). These differences are considered population-level variation and, as only one species of Alofia, A. merki, has been identified from Australia and in areas overlapped by this study, these nymphs have all been identified as $A$. merki.

Sebekia purdieae Riley, Spratt et Winch, $1990 \quad$ Fig. 3

Description. Infective nymph (based on 4 specimens for each measurement). Fresh specimens off-white in colour. Body $6.0-7.3 \mathrm{~mm}(6.6 \mathrm{~mm})$ long by 700-760 (733) wide. Annuli margins easily discernible in whole mounts, average count, including annuli with interrupted rows of spines, 76-85 (81).

Hooks arranged in trapezoid pattern around mouth opening (Fig. 3A). Anterior and posterior hooks sharp-tipped, all with dorsal accessory piece (Fig. 3B). Hooks and dorsal accessory shields visible under dissector microscope. Fulcra short, stout, slightly curved. Anterior hooks: dorsal accessory piece 86-106 (97), AC 83-96 (89), AD 102-109 (106), BC 58-64 (61), CD 16-32 (23), AB 42-50 (47), fulcrum length 230-245 (238); posterior hooks: dorsal accessory piece 93-106 (101), AC 83-90 (88), AD 90-102 (98), BC 54-64 (59), CD 19-32 (29), AB 30-48 (41), fulcrum length 204-245 (220). Measurements for individual nymphs presented in Table S5.

Buccal cadre O-shaped (Fig. 3C), anterior edge closed, although under coverslip pressure may split. Sides of cadre thin and smooth to slightly crenulated along length. Posterior edge of oral cadre rounded, thick, slight tapering into oesophagous. Oral cadre situated between fulcra of anterior hook pair. Buccal cadre 114-130 (124) long by $65-86$ (77) wide.

Body carries conspicuous rows of sharply pointed projecting spines along posterior edge of each annulus (Fig. 3A,D). First row interrupted. Spines well visible on 
anterior annulus but more difficult to detect posteriorly. Total length of spines 11-12 (in anterior part of body), embedded basal swelling approximately same length as spine (Fig. 3D). Chloride cells disposed in single row along anterior edge of annuli (Fig. 3D). Chloride cells measure 9.5 in diameter. Anus terminal; rectum lined with thin cuticle.

Ho st: Protonibea diacanthus (Lacepède) (Sciaenidae).

Site of infection: Encysted within capsule within host mesentery tissues.

L o calities: Wyndham, Liverpool River (see Materials and Methods for details).

Prevalence and intensity: Overall 3 of $315(1 \%), 1.3$ (1-2); Wyndham 2 of 34 (6\%), 1.5 (1-2); Liverpool River 1 of $24(4 \%)$.

Remarks. Sebekia was erected by Sambon (1922) for species of pentastomes collected from crocodiles and monitor lizards from the Americas, Africa and the Far East. The main identifying factor for members of the genus was the presence of spines on the dorsal surface of the hooks (Sambon 1922, Riley et al. 1990). These spines, however, are only present in the adult and have also been subsequently reported, at lesser degrees of development, in species of other genera, such as Alofia and Selfia Riley, 1994 (see Riley 1994, Riley and Hurchzermeyer 1995). Poore (2012) listed 12 species of Sebekia, of which three species were recorded from northern Australia. Riley et al. (1985) reported an additional Sebekia sp. based on a single female specimen collected from C. porosus near the Peron Islands, Northern Territory (which was not listed by Poore 2012). Riley et al. (1990) considered this a potential separate species to the other Australian species based on its hook measurements.

Infective nymphal specimens for two of the Australian species were collected and described by Riley et al. (1990). From the measurements reported in Riley et al. (1990), the female nymphs of S. johnstoni and S. multiannulata overlap in hook measurements; the only truly distinguishing feature of $S$. johnstoni is the much lower annulus count (61-72 compared to 88-96; see Riley et al. 1990). Differentiation between $S$. multiannulata and $S$. purdieae is more difficult; in general, despite overlapping annuli counts, S. purdieae has larger AD and fulcrum lengths in adult males and females (Riley et al. 1990).

A total of 19 nymphs were identified as members of the genus Sebekia Sambon, 1922 based on the combination of the closed buccal cadre, shape and size of the hooks and its small body size (see Riley et al. 1990). DNA analysis of six specimens of Sebekia determined the presence of three species through $18 \mathrm{~S}$ and $28 \mathrm{~S}$ sequences (Tables S5, S6); differentiation by the mtDNA coxl gene was not as clear due to variable PCR amplification success. Confirmation of the identity of the nymphs to the previously described species of Sebekia was difficult. The majority of nymphs of Sebekia examined were collected from A. macleayi (AWC P31). Morphologically, the specimens were very similar and would appear to belong to a single species (Table S6). Unfortunately, DNA extraction failed for the specimen from this collection (NTM D1565), most likely due to preserva-
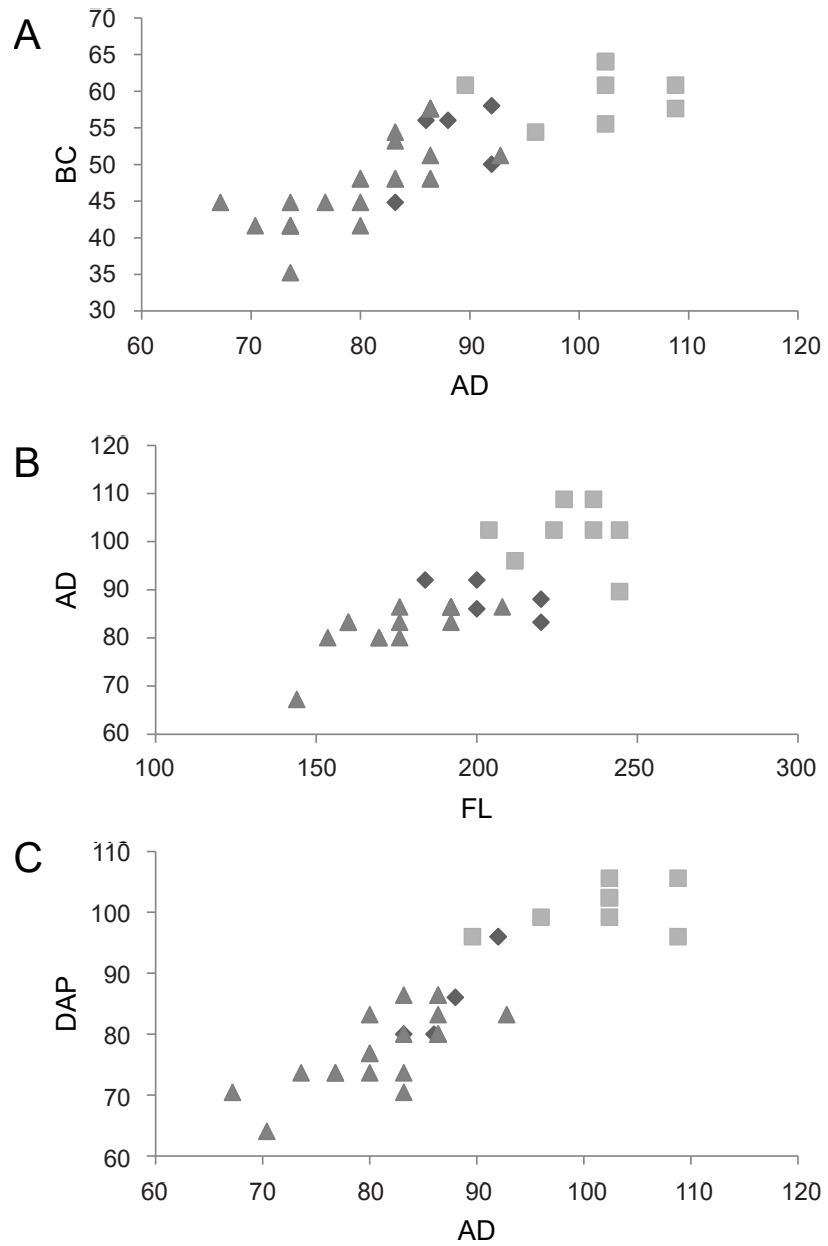

Fig. 4. Hook dimensions of nymphs of Sebekia spp. collected from fish in Australia. Nymphs determined as Sebekia purdieae Riley, Spratt et Winch, $1990(\square)$ were collected from Protonibea diacanthus (Lacepède) in Wyndham, Western Australia, and the Liverpool River, Northern Territory; nymphs designated as Sebekia sp. were collected from Ambassis macleayi (Castelnau) from a dam at the Noonamah Crocodile Farm, near Darwin, Northern Territory $(\boldsymbol{\Delta})$, and from Protonibea diacanthus from Wyndham, Western Australia, and the Adelaide River, Northern Territory $(\bullet)$. A - hook length (AD) $v$ s base length (BC); B - fulcrum length (FL) $v s$ hook length (AD); $\mathbf{C}$ - hook length (AD) $v s$ length of dorsal accessory piece (DAP).

tion technique. The remaining seven nymphs of Sebekia were collected fresh in the present study, of which five were examined genetically. Two specimens collected from $P$. diacanthus from Wyndham (NTM D1564) and Liverpool River (NTM D1563) were found to be a $100 \%$ genetic match (Table S5). Measurements of these two specimens were consistently larger for $\mathrm{AD}$, dorsal accessory piece and fulcrum length in comparison to the other nymphs collected, characteristics consistent with the differentiation of adult $S$. purdieae by Riley et al. (1990); unfortunately, nymphs of $S$. purdieae have not previously been collected to allow for a direct comparison. However, comparison of the relationships of various morphological features for the nymphs identified as S. purdieae (Table S5) in comparison to the remaining Sebekia spp. showed that four specimens could be attributed to $S$. purdieae (Table S5, Fig. 4). We 

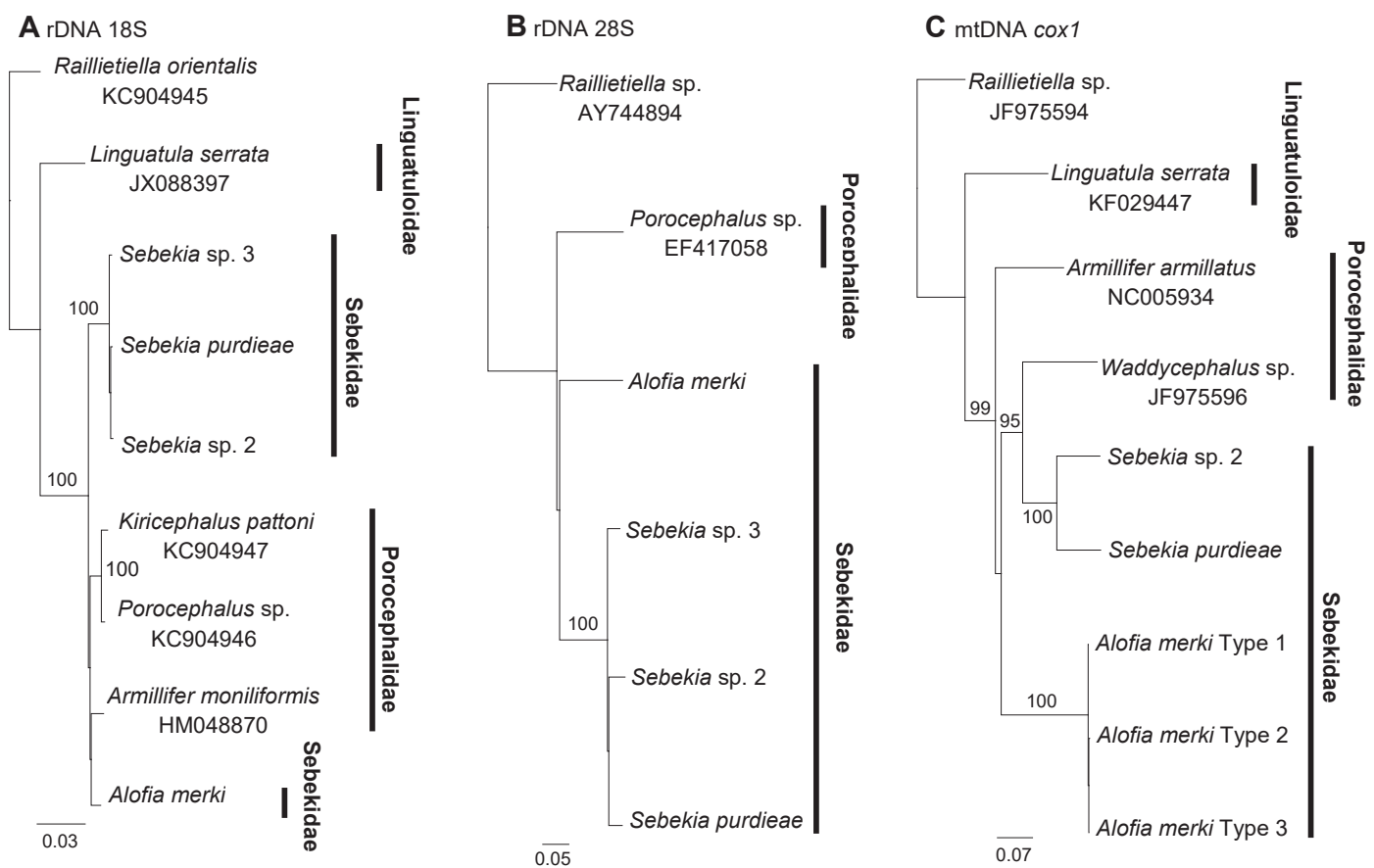

Fig. 5. Neighbour-joining phylogenetic trees of the order Porocephalida with sister order, Raillietiellida, used as outgroup. A - rDNA 18S - 1742 bases; B - rDNA 28S - 1286 bases; C - mtDNA cox 1 - 604 bases. Numbers (only shown if over 75\%) indicate branch support via bootstrapping.

are confident in the identification of nymphs as $S$. purdieae but stress that genetic confirmation of adult specimens is still required.

The specimen collected from $P$. diacanthus in Wyndham (NTM D1548) was determined genetically as Sebekia sp. 2. Some morphological measurements could be obtained from this specimen, but the number of annuli (a species-determining characteristic) could not be determined. The host for this specimen was the same as for two of the specimens of $S$. purdieae, showing that mixed infections do occur. The specimen collected from $P$. diacanthus in the Adelaide River (NTM D1538) was determined genetically as Sebekia sp. 3. Unfortunately, the anterior end of this specimen was lost prior to morphological analysis so no morphological measurements were available. Measurements reported for infective nymphs of $S$. johnstoni and $S$. multiannulata overlap, with the number of annuli being the major distinguishing character. The hook measurements available for the remaining nymphs were all within the ranges reported for S. johnstoni and S. multiannulata, but the majority of specimens had annuli counts closest to $S$. johnstoni. However, as the specimen identified as Sebekia sp. 2 did not have an annulus count to verify which species it belonged to, identification could not be taken further. Measurements of individual nymphs are provided in Tables S5, S6. Comparison of hook measurements (Fig. 4) did not provide a clear discrimination between the remaining specimens of Sebekia spp. collected from A. macleayi and $P$. diacanthus.

Although our genetic analyses confirm the presence of three species of Sebekia within Australia, the true identification of at least two of these species cannot be determined at this stage. Further study of nymphal specimens, as well as of adult specimens collected from crocodiles, is required utilising both morphological and genetic techniques to confirm the remaining species identities.

\section{Molecular analyses}

Although limited to the available published sequence data for comparison, the phylogenetic analyses place both Sebekia and Alofia well within the order Porocephalida. The grouping of these two species into the family Sebekidae is not supported by the rDNA $18 \mathrm{~S}$ or the mtDNA cox 1 trees (Fig. 5A,C); instead they show affiliations with members of the family Porocephalidae Sambon, 1922. The conserved rDNA $18 \mathrm{~S}$ marker suggests Alofia may be better placed in the family Porocephalidae while the variable mtDNA cox 1 gene suggests Sebekia is more closely related to Waddycephalus Sambon, 1922 (Porocephalidae) than to Alofia. The rDNA $28 \mathrm{~S}$ marker unfortunately has limited phylogenetic power at this time due to the lack of sequences from other porocephalid families (Fig. 5B).

\section{DISCUSSION}

This is the first report of nymphal pentastomes from a fish host in Australian waters. The pentastomes were identified as belonging to the Sebekidae, adults of which mature in crocodiles and have previously been reported from Australian hosts (see Riley et al. 1985, 1990, Riley 1994, Riley and Huchzermeyer 1996, Junker and Boomker 2006).

As for many sexually dimorphic parasites, a mature adult specimen is preferred for accurate species determination since measurements, such as body length, are not affected by the extent of egg development as in females, and copulatory spicules offer additional morphological 
characteristics; nymphal stages possess few characteristics of taxonomic importance. Many infections of pentastomes in crocodiles are dominated by females, however, with few or no males found (Junker et al. 1999). Adding to the confusion, in crocodiles, many pentastome infections are composed of two or more species (and genera) (see Riley and Hurchzermeyer 1995 for an example where a single crocodile was infected with at least three Sebekia spp. and one Alofia sp.), of which the females overlap in measurements of many of the species-determining characteristics. Pentastome infections in the definitive host may also include a combination of nymphal, immature and mature specimens, of which only the fully mature individuals can give a truly accurate species identification.

Infective nymphs of the Sebekidae can be readily identified to genus, based mainly on the shape of the buccal cadre (see Giesen et al. 2013): specimens of Alofia have a buccal cadre with a characteristic U-shape and 'tuning fork' posterior end, whereas nymphs of Sebekia possess a rounded buccal cadre. The use of hook measurements for species identification of nymphs is problematic. The hook morphology of sebekids differs markedly between nymphal and adult forms. Nymphal hooks possess a dorsal accessory piece and are aspinous, whereas adult hooks have no accessory piece and may possess spines. The relative proportions of the $\mathrm{AC}$ and $\mathrm{CD}$ lengths to the overall length (AD) of the nymphal and adult hooks are also markedly different. Additionally, in some descriptions, the overall length (AD) measurement of nymphal hooks appears to be larger than for the corresponding adult hooks (see measurements of nymphal and immature adult female Sebekia multiannulata in Riley et al. 1990). Due to the lack of nymphal descriptions for many species, whether this is a true relationship or due to nymphs being attributed to the wrong species is unknown. It will probably only be after more molecular analyses are completed and relationships between nymphal and adult stages confirmed, that this quandary with the hook measurements will be resolved.

The phylogenetic analysis results indicated that Alofia and Sebekia are probably not sister taxa within the Sebekidae and that the familial relationships of the Porocephalidae and Sebekidae should be reviewed. However, a paucity of available sequences across a range of genera means that these results are still preliminary.

Little is known about the intermediate hosts of the pentastomid parasites of crocodiles in general (Junker et al. 1998) and no potential intermediate hosts for pentastomids of crocodiles in Australia have previously been reported. Host specificity of pentastome nymphs in fish intermediate hosts appears to be low, with nymphs found in a variety of hosts within a single aquatic system (Almeida et al. 2010, Giesen et al. 2013). Indeed, four very different fish species were found to be intermediate hosts in this study. The specimens of Alofia macleayi were collected from a dam on a crocodile farm and may not represent a true intermediate host in the wild. Both Protonibea diacanthus and Lates calcarifer are known to be diadromous, able to move between fresh and marine waters throughout their life cycle, whereas Lutjanus johnii is regarded as a marine/estuarine species (Froese and Pauly 2015). Ecologically, in wild populations, the sebekid nymphs appear to be more common in diadromous fish species. A survey of other fish species as well as alternative intermediate hosts, such as mud crabs (Scylla serrata Forskål; Portunidae), which are common dietary items for wild Crocodilus porosus (see Webb and Manolis 1989), from upper reaches of some river systems of the Northern Territory, especially those where pentastomids have already been reported in wild crocodiles, might find more infected animals.

There has been no systematic survey of the pentastomes of crocodiles in Australia, however, to determine the true range of pentastome genera and species present, so it is highly likely that more species and/or genera are yet to be found. Care, however, needs to be taken before ascribing specimens to a particular, or new, species. Only the fully mature individuals possess features that permit accurate species identification. Reliable morphological descriptions, in combination with genetic characterisation, are needed to resolve species identity and relationships within this group. The present study provides the baseline genetic data and morphometric characters to enable further studies on these enigmatic parasites.

Acknowledgements. The authors thank the staff of the Northern Territory Department of Primary Industries and Fisheries, the Western Australian Department of Agriculture and Fisheries, and the Queensland Department of Agriculture and Fisheries Long Term Monitoring Program, as well as various recreational and commercial fishers, for the collection of host specimens. This study was supported by the Australian Fisheries Research and Development Corporation (Project No. 2013/017) and an Australian Biological Resources Study grant (No. CN213-07). The authors are indebted to David Spratt (CSIRO, Gunghalin), Kate Hutson (James Cook University, Townsville) and Thierry Laperousaz (South Australian Museum, Adelaide) for the loan of specimens for comparison. We are indebted to Thierry Laperousaz for permission to remount slide material. The senior author thanks David Spratt for his support and lively debate on all things pentastome.

\section{REFERENCES}

Almeida W.O., Silva-Souza A.T., Sales D.L. 2010: Parasitism of Phalloceros harpagos (Cyprinodotinformes: Poeciliidae) by Sebekia oxycephala (Pentastomida: Sebekidae) in the headwaters of the Cambé River, Paraná State, Brazil. Braz. J. Biol. 70: $457-458$.

Curran S.S., Overstreet R.M., Collins D.E., Benz G.W. 2014: Levisunguis subaequalis n. g., n. sp., a tongue worm (Pentastomida: Porocephalida: Sebekidae) infecting softshell turtles,
Apalone sp., (Testudines: Trionychidae) in the southeastern United States. Syst. Parasitol 87: 33-45.

Dreyer H., Wagele J.-W. 2001: Parasites of crustaceans (Isopoda: Bopyridae) evolved from fish parasites: molecular and morphological evidence. Zoology 103: 157-178.

Froese R., Pauly D. (Eds.) 2016: FishBase. World Wide Web electronic publication. www. fishbase.org, 01/2016. 
Geller J., Meyer C., Parker M., Hawk H. 2013: Redesign of PCR primers for mitochondrial cytochrome c oxidase subunit I for marine invertebrates and application in all-taxa biotic surveys. Mol. Ecol. Resour. 13: 851-861.

Giesen S.C., Takemoto R.M., Calitz F., De los Angeles Perez Lizama M., Junker K. 2013: Infective pentastomid larvae from Pygocentrus mattereri Kner (Pisces, Characcidae) from the Miranda River, Pantanal, Mato Grosso do Sul State, Brazil, with notes on their taxonomy and epidemiology. Folia Parasitol. 60: 457-468.

Giglioli G. 1922: The new genus Alofia of the family Linguatulidae. An anatomical account of $A$. ginae. J. Trop. Med. Hyg. 25: 371-377.

Guidelli G.M., IsaAc A., Takemoto R.M., Pavanelli G.C. 2003: Endoparasite infracommunities of Hemisorubium platyrhynchos (Valenciennes, 1840) (Pisces: Pimelodidae) of the Baía River, upper Paraná River floodplain, Brazil: specific composition and ecological aspects. Braz. J. Biol. 63: 261-268.

Junker K., Boomker J. 2006: A check-list of the pentastomid parasites of crocodilians and freshwater chelonians. Onderstepoort J. Vet. Res. 73: 27-36.

Junker K., Boomker J., Bolton L.A. 1999: Pentastomid infections in Nile crocodiles (Crocodylus niloticus) in the Kruger National Park, South Africa, with a description of the males of Alofia simpsoni. Onderstepoort J. Vet. Res. 66: 65-71.

Junker K., Boomker J., Booyse D.G. 1998: Pentastomid infections in cichlid fishes in the Kruger National Park and the description of the infective larva of Subtriquetra rileyi n. sp. Onderstepoort J. Vet. Res. 65: 159-167.

Kearse M., Moir R., Wilson A., Stones-Havas S., Cheung M., Sturrock S., Buxton S., Cooper A., Markowitz S., Duran C., Thierer T., Ashton B., Meintues P., DrumMOND A. 2012: Geneious Basic: an integrated and extendable desktop software platform for the organization and analysis of sequence data. Bioinformatics 28: 1647-1649.

Poore G.C.B. 2012: The nomenclature of the recent Pentastomida (Crustacea), with a list of species and available names. Syst. Parasitol. 82: 211-240.

Raupach M.J., Mayer C., Malyutina M., Wägele J.-W. 2009 Multiple origins of deep-sea Asellota (Crustacea: Isopoda) from shallow waters revealed by molecular data. Proc. Biol. Sci. 276 : 799-808.

Riley J. 1994: A revision of the genus Alofia Giglioli, 1922 and a description of a new monotypic genus, Selfia: two genera of pentastomid parasites (Porocephalida: Sebekidae) inhabiting the bronchioles of the marine crocodile Crocodylus porosus and other crocodilians. Syst. Parasitol. 26: 23-41.

Riley J., Huchzermeyer F.W. 1995: Descriptions of four species of pentastomid parasites belonging to the genera Alofia Giglioli, 1922 and Sebekia Sambon, 1922, from a single Nile crocodile Crocodylus niloticus from Botswana. Syst. Parasitol. 31: 221238.

Riley J., Huchzermeyer F.W. 1996: A reassessment of the pentastomid genus Leiperia Sambon, 1922, with a description of a new species from both the Indopacific crocodile Crocodylus porosus and Johnson's crocodile C. johnsoni in Australia. Syst. Parasitol. 34: 53-66.

Riley J., Spratt D.M., Presidente P.J.A. 1985: Pentastomids (Arthropoda) parasitic in Australian reptiles and mammals. Aust. J. Zool. 33: 39-53.

Riley J., Spratt D.M., Winch J.M. 1990: A revision of the genus Sebekia Sambon, 1922 (Pentastomida) from crocodilians with descriptions of five new species. Syst. Parasitol. 16: 1-25.

SAmbon L.W. 1922: A synopsis of the family Linguatulidae [part I]. J. Trop. Med. Hyg. 25: 188-206.

Self J.T., Rego A.A. 1985: Reassessments and revisions of certain genera and species of the family Sebekidae (Pentastomida) including description of Sebekia microhamus n. sp. Syst. Parasitol. 7: $33-41$.

Sonnenberg R., Nolte A.W., TAutz D. 2007: An evaluation of LSU rDNA D1-D2 sequences for their use in species identification. Front. Zool. 4: 6.

Webi G., Manolis C. 1989: Crocodiles of Australia. Reed Books, Chatswood, $160 \mathrm{pp}$.

Winch J.M., Riley J. 1986: Morphogenesis of larval Sebekia oxycephala (Pentastomida) from a South American crocodilian (Caiman sclerops) in experimentally infected fish. Z. Parasitenkd. 72: 251-264.

Cite this article as: Barton D.P., Morgan J.A.T. 2016: A morphological and genetic description of pentastomid infective nymphs belonging to the family Sebekidae Sambon, 1922 in fish in Australian waters. Folia Parasitol. 63: 026. 